\title{
Deposition of $\mathrm{Ru}$ and $\mathrm{RuO}_{2}$ thin films employing dicarbonyl bis-diketonate ruthenium complexes as CVD source reagents
}

\author{
Ying-Hui Lai, ${ }^{a}$ Yao-Lun Chen, ${ }^{a}$ Yun Chi, ${ }^{a}$ Chao-Shiuan Liu, ${ }^{a}$ Arthur J. Carty, ${ }^{* b}$ \\ Shie-Ming Peng ${ }^{c}$ and Gene-Hsiang Lee ${ }^{c}$ \\ ${ }^{a}$ Department of Chemistry, National Tsing Hua University, Hsinchu 300 Taiwan, ROC. \\ E-mail: ychi@mx.nthu.edu.tw; Fax: (886) 3572-0864 \\ ${ }^{b}$ Steacie Institute for Molecular Sciences, National Research Council Canada, 100 Sussex \\ Drive, Ottawa, Ontario, K1A0R6, Canada.E-mail: arthur.carty@nrc-cnrc.gc.ca \\ ${ }^{c}$ Department of Chemistry, National Taiwan University, Taipei 106 Taiwan, ROC
}

Received 14th January 2003, Accepted 16th May 2003
First published as an Advance Article on the web 9th June 2003

Reaction of $\mathrm{Ru}_{3}(\mathrm{CO})_{12}$ with 6 eq. of $\beta$-diketone ligands (hfac) $\mathrm{H}$, (tmhd) $\mathrm{H}$, (acac)H and (tfac) $\mathrm{H}$ at $160-170{ }^{\circ} \mathrm{C}$ in a hydrocarbon solvent (pentane or hexane) affords the diketonate complexes $\left[\mathrm{Ru}(\mathrm{CO})_{2}(\mathrm{hfac})_{2}\right](\mathbf{1})$,

$\left[\mathrm{Ru}(\mathrm{CO})_{2}(\mathrm{tmhd})_{2}\right](2),\left[\mathrm{Ru}(\mathrm{CO})_{2}(\mathrm{acac})_{2}\right](3)$ and $\left[\mathrm{Ru}(\mathrm{CO})_{2}(\mathrm{tfac})_{2}\right](4)$ in high yields. These ruthenium complexes were characterized by spectroscopic methods; a single crystal X-ray diffraction study was carried out on one isomer of the tfac complex (4a), revealing an octahedral coordination geometry with two CO ligands located at cis-positions and with the $\mathrm{CF}_{3}$ groups of the $\beta$-diketonate ligands trans to the $\mathrm{CO}$ ligands. Thermogravimetric analysis of complex (1) showed an enhanced volatility compared to the parent acac complex (3), attributed to the $\mathrm{CF}_{3}$ group reducing intermolecular attraction. Employing complexes (1) and (2) as CVD source reagents, ruthenium thin films can be deposited at temperatures of $350{ }^{\circ} \mathrm{C}-450{ }^{\circ} \mathrm{C}$ under an $\mathrm{H}_{2}$ atmosphere or at temperatures of $275{ }^{\circ} \mathrm{C}-400{ }^{\circ} \mathrm{C}$ using a $2 \%$ mixture of $\mathrm{O}_{2}$ in argon as carrier gas. For deposition carried out using complex (1) and under $100 \% \mathrm{O}_{2}$ atmosphere, $\mathrm{RuO}_{2}$ thin films with a preferred (200) orientation were obtained. The as-deposited thin films were characterized by surface and physical analytical techniques, such as scanning electron microscopy (SEM), X-ray photoelectron spectroscopy (XPS), X-ray diffraction analysis (XRD) and four-point probe measurement.

Ruthenium-containing thin films show great promise for fabricating bottom electrodes or non-corrosive diffusion barriers for next generation, tantalum oxide $\left(\mathrm{Ta}_{2} \mathrm{O}_{5}\right)$, barium strontium titanate (BST) and lead zirconate titanate (PZT) based nonvolatile random access memory (RAM) devices. ${ }^{1}$ The advantages of ruthenium over other conducting materials include: lower resistivity, good etching ability, good barrier properties against oxygen diffusion, high resistance against capacitor shorting due to the formation of hillocks, severe polarization fatigue and aging. ${ }^{2}$ Moreover, its oxide phase, $\mathrm{RuO}_{2}$, which crystallizes in the rutile structure, belongs to a class of conductive oxide materials that exhibit excellent chemical stability at higher temperatures in $\mathrm{O}_{2}$ ambient. These combined characteristics make $\mathrm{RuO}_{2}$ an idea candidate for the fabrication of diffusion barriers for contact metallizations in very large scale integration (VLSI) applications, buffer layers of high $T_{\mathrm{c}}$ superconducting films on silicon, and electrodes of ferroelectric thin films.

Chemical vapor deposition (CVD) has received more attention in recent years, particularly in depositing these ruthenium-containing thin films, for its obvious capability of alleviating problems associated with the physical vapor deposition or sputtering process, such as low conformal coverage, poor crystallinity, and high stress level. As a result, several Ru metal-containing complexes have been examined as potential CVD precursors, including (a) ruthenocene ${ }^{3}$ and its alkyl substituted derivatives such as $\mathrm{Ru}\left(\mathrm{C}_{5} \mathrm{H}_{4} \mathrm{Et}\right)_{2},{ }^{4}$ (b) metal carbonyl complexes, such as $\mathrm{Ru}(\mathrm{CO})_{3}\left(\mathrm{C}_{6} \mathrm{H}_{8}\right),{ }^{5} \mathrm{Ru}(\mathrm{CO})_{4}(\mathrm{hfb}),{ }^{6}$ $\mathrm{hfb}=$ hexafluoro-2-butyne, and $\mathrm{Ru}_{3}(\mathrm{CO})_{12},{ }^{7}$ (c) tris- $\beta$ diketonate coordination complexes, such as $\mathrm{Ru}(\mathrm{acac})_{3}$, $\mathrm{Ru}(\mathrm{tfac})_{3}$ and $\mathrm{Ru}(\mathrm{tmhd})_{3}$, tfac $=1,1,1$-trifluoro-2,4-pentanedionate and tmhd $=2,2,6,6$-tetramethyl-3,5-heptanedionate, ${ }^{8}$ and (d) organo- metallic alkenyl and alkene complexes of bis(2,4-dimethylpentadienyl)ruthenium, ${ }^{9}$ and arene complexes such as $\left(\eta^{6}-\mathrm{C}_{6} \mathrm{H}_{6}\right) \mathrm{Ru}\left(\eta^{4}-\mathrm{C}_{6} \mathrm{H}_{8}\right), \mathrm{C}_{6} \mathrm{H}_{8}=1,3$-cyclohexadiene, and $\mathrm{Ru}\left(\mathrm{C}_{3} \mathrm{H}_{5}\right)_{2}(\mathrm{COD}), \mathrm{COD}=1,4$-cyclooctadiene. ${ }^{10}$ However, only one of them, i.e. $\mathrm{Ru}\left(\mathrm{C}_{5} \mathrm{H}_{4} \mathrm{Et}\right)_{2}$, was tested on the pilot scale using six-inch silicon wafers as substrates. ${ }^{4 a}$ The rest of the source reagents were not used in the large scale process due to their poor thermal stabilities, or the involvement of laborious synthetic manipulations.

Accordingly, there is a strong demand for better Ru CVD source reagents, which should possess advantages such as: suitability for scale-up synthetic operation, higher thermal and oxidative stability during storage, higher volatility upon heating, and the capability to induce facile metal deposition under designated CVD conditions. In this paper, we report our attempt targeted at the preparation of possible Ru CVD source reagents that would satisfy most of these stringent requirements. Part of this investigation was published as a preliminary communication and a patent document. ${ }^{11}$

\section{Experimental}

\section{General information and materials}

All synthetic experiments were conducted using a $160 \mathrm{~mL}$ Parr Instrument, series $4772 \mathrm{Q}$ stainless steel autoclave, with a 4316 gauge block assembly and a thermocouple. Mass spectra were obtained on a JEOL SX-102A instrument operating in electron impact (EI) mode, and infrared spectra were recorded on a Perkin-Elmer 2000 FT-IR spectrometer. The ${ }^{1} \mathrm{H},{ }^{13} \mathrm{C}$ and ${ }^{19}$ F NMR spectra were recorded on a Varian Mercury-400 instrument; chemical shifts are quoted with respect to internal standard tetramethylsilane for ${ }^{1} \mathrm{H}$ and ${ }^{13} \mathrm{C}$ NMR data and $\mathrm{CFCl}_{3}$ for ${ }^{19} \mathrm{~F}$ NMR data. The thermogravimetric analyses 
(TGA) were recorded on a Seiko TG/DTA 300 instrument under $\mathrm{N}_{2}$ at $1 \mathrm{~atm}$, with a constant flow rate of $100 \mathrm{sccm}$ (standard cubic centimeter per minute) and a heating rate of $10{ }^{\circ} \mathrm{C} \mathrm{min}^{-1}$. All reactions were performed in air using anhydrous solvents or solvents treated with an appropriate drying reagent.

The $\mathrm{Ru}$ and $\mathrm{RuO}_{2}$ thin film samples was analyzed using a Mac Science, M18XCE X-ray diffractometer with $\mathrm{Cu} \mathrm{K}_{\alpha}$ radiation (XRD). Scanning electron microscopy (SEM) was performed using a Hitachi S-4000 system. The electrical resistivity of films was measured by a four-point probe method at room temperature, for which the instrument is assembled using a Keithley 2182 nanovoltmeter and a Keithley 2400 constant current source. The elemental composition was determined by X-ray photoelectron spectroscopy (XPS) utilizing a Physical Electronics PHI 1600 system with an Al/ $\mathrm{Mg}$ dual anode X-ray source, and the XPS spectra were collected after 1-2 min sputtering with argon at $4 \mathrm{keV}$ until a constant composition was obtained. In general, the $\mathrm{C}_{1 \mathrm{~s}}$ peak overlaps with the $\mathrm{Ru} 3 \mathrm{~d}_{3 / 2}$ peak at binding energy (BE) $284 \mathrm{eV}$ in the XPS survey scan and direct measurement of the carbon content is impossible. However, the $\mathrm{Ru} 3 \mathrm{~d}_{5 / 2}$ peak at $\mathrm{BE} 280 \mathrm{eV}$ does not overlap with any carbon signals, and the $3 \mathrm{~d}_{5 / 2} / 3 \mathrm{~d}_{3 / 2}$ peak intensity ratio of pure Ru metal should be nearly $3: 2$, which corresponds to the theoretical value due to spin-orbit interactions of d-electrons. ${ }^{12}$ If carbon were indeed present in the $\mathrm{Ru}$ film, the observed $3 \mathrm{~d}_{5 / 2} / 3 \mathrm{~d}_{3 / 2}$ integration ratio would show a deviation from the ideal value of $3: 2$. Thus, slow scans over these regions of interest were utilized as a gauge of the carbon content, followed by least-squares curve fitting and deconvolution. The spectral deconvolution procedures were carried out using a nonlinear least squares fitting program adopting mixed Gaussian-Lorentzian line shape and Shirley baselines.

Synthesis of complex (1). A sample of $\mathrm{Ru}_{3}(\mathrm{CO})_{12}(0.5 \mathrm{~g}$, $0.78 \mathrm{mmol})$, six equivalents of (hfac) $\mathrm{H}(0.7 \mathrm{~mL}, 4.9 \mathrm{mmol})$, and $50 \mathrm{~mL}$ of anhydrous pentane together with a stirring bar were added into a $160 \mathrm{~mL}$ stainless steel autoclave. The autoclave was sealed and then slowly heated under stirring to $160{ }^{\circ} \mathrm{C}$ for 18 hours. After cooling the autoclave to room temperature, the pentane solution was transferred out of the reactor and filtered to remove any insoluble precipitates present in the reaction mixture. The filtrate was concentrated on a rotary evaporator very briefly, and the resulting solid residue was dissolved into a minimum amount of warm methanol. Cooling the methanol solution to $-20{ }^{\circ} \mathrm{C}$ produced $1.27 \mathrm{~g}$ of the light orange $\mathrm{Ru}(\mathrm{CO})_{2}(\mathrm{hfac})_{2}(92 \%)$ with melting point $64-66^{\circ} \mathrm{C}$.

Spectral data of (1): MS (FAB, $\left.{ }^{102} \mathrm{Ru}\right), \mathrm{m} / z$ 572. IR $\left(\mathrm{C}_{6} \mathrm{H}_{12}\right)$ : $v(\mathrm{CO}), 2092$ (s), 2036 (vs) $\mathrm{cm}^{-1} .{ }^{1} \mathrm{H}$ NMR $\left(\mathrm{CDCl}_{3}, 298 \mathrm{~K}\right)$ : $\delta 6.34(\mathrm{~s}, 2 \mathrm{H}, \mathrm{CH}) .{ }^{13} \mathrm{C} \mathrm{NMR}\left(\mathrm{CDCl}_{3}, 298 \mathrm{~K}\right): \delta 192.5(2 \mathrm{C}$, $\mathrm{CO}), 179.1\left(2 \mathrm{C}, \mathrm{CO},{ }^{2} J_{\mathrm{CF}}=36 \mathrm{~Hz}\right), 176.9\left(2 \mathrm{C}, \mathrm{CO},{ }^{2} J_{\mathrm{CF}}=\right.$ $36 \mathrm{~Hz}), 116.7\left(2 \mathrm{C}, \mathrm{CF}_{3},{ }^{1} J_{\mathrm{CF}}=285 \mathrm{~Hz}\right), 115.9\left(2 \mathrm{C}, \mathrm{CF}_{3},{ }^{1} J_{\mathrm{CF}}\right.$ $=285 \mathrm{~Hz}), 91.8(2 \mathrm{C}, \mathrm{CH}) .{ }^{19} \mathrm{~F}\left(\mathrm{CDCl}_{3}, 298 \mathrm{~K}\right): \delta-74.15(\mathrm{~s}$, $6 \mathrm{~F}),-75.06$ (s, 6F). Anal. Calcd for $\mathrm{C}_{12} \mathrm{H}_{2} \mathrm{~F}_{12} \mathrm{O}_{6} \mathrm{Ru}$ : C, 25.23; $\mathrm{H}, 0.35$. Found: $\mathrm{C}, 25.45 ; \mathrm{H}, 0.40 \%$.

Synthesis of complex (2). To a $160 \mathrm{~mL}$ stainless steel autoclave was added $0.5 \mathrm{~g}$ of $\mathrm{Ru}_{3}(\mathrm{CO})_{12}(0.78 \mathrm{mmol}), 1.0 \mathrm{~mL}$ of (tmhd)H ( $4.8 \mathrm{mmol}), 50 \mathrm{~mL}$ of hexane and a magnetic stirring bar. The autoclave was sealed and slowly brought to a temperature of $160{ }^{\circ} \mathrm{C}$ under constant stirring. After 18 hours, the autoclave was cooled to room temperature and then opened. The light yellow solution was transferred out of the reactor. The hexane solvent was evaporated under vacuum and the residue dissolved into a minimum of warm methanol solvent. Cooling the methanol solution to $-20{ }^{\circ} \mathrm{C}$ produced a light yellow solid $\mathrm{Ru}(\mathrm{CO})_{2}(\mathrm{tmhd})_{2}$, which was collected by filtration. Yield: $1.11 \mathrm{~g}, 2.11 \mathrm{mmol}, 90 \%$. Further purification of this compound was carried out by sublimation at $80{ }^{\circ} \mathrm{C}$ and 300 mTorr.
Spectral data of (2): MS (EI, $\left.{ }^{102} \mathrm{Ru}\right), \mathrm{m} / \mathrm{z} 524\left(\mathrm{M}^{+}\right)$. IR $\left(\mathrm{C}_{6} \mathrm{H}_{12}\right): v(\mathrm{CO}), 2053(\mathrm{~s}), 1985$ (vs) $\mathrm{cm}^{-1} \cdot{ }^{1} \mathrm{H} \mathrm{NMR}\left(\mathrm{CDCl}_{3}\right.$, $294 \mathrm{~K}): \delta 5.62(\mathrm{~s}, 2 \mathrm{H}, \mathrm{CH}), 1.09\left(\mathrm{~s}, 18 \mathrm{H}, \mathrm{CH}_{3}\right), 1.04(\mathrm{~s}, 18 \mathrm{H}$, $\left.\mathrm{CH}_{3}\right) .{ }^{13} \mathrm{C} \mathrm{NMR}\left(\mathrm{CDCl}_{3}, 294 \mathrm{~K}\right): \delta 199.1(2 \mathrm{C}, \mathrm{CO}), 198.4(2 \mathrm{C}$, CO), 197.0 (2C, CO), 98.6 (2C, CH), 42.1 (2C), 41.1 (2C), 28.7 $\left(6 \mathrm{C}, \mathrm{CH}_{3}\right), 28.5\left(6 \mathrm{C}, \mathrm{CH}_{3}\right)$. Anal. Calcd for $\mathrm{C}_{24} \mathrm{H}_{38} \mathrm{O}_{6} \mathrm{Ru}$ : C, 55.05; H, 7.31. Found: C, 55.37; H, 7.53\%.

Synthesis of complex (3). A similar procedure was followed, using (acac)H as starting material rather than (hfac)H or (tmhd)H. The autoclave was heated at $160{ }^{\circ} \mathrm{C}$ for 24 hours. After removing the hexane solvent, recrystallization of the solid residue from methanol at $4{ }^{\circ} \mathrm{C}$ gave yellow-orange crystalline solid $\left[\mathrm{Ru}(\mathrm{CO})_{2}(\mathrm{acac})_{2}\right]$ in $85 \%$ yield. The compound melted at $115-117^{\circ} \mathrm{C}$.

Spectral data of (3): MS (EI, $\left.{ }^{102} \mathrm{Ru}\right): m / z 356\left(\mathrm{M}^{+}\right)$. IR $\left(\mathrm{C}_{6} \mathrm{H}_{12}\right): v(\mathrm{CO}), 2056$ (s), 1988 (vs) $\mathrm{cm}^{-1} .{ }^{1} \mathrm{H}$ NMR $\left(\mathrm{CDCl}_{3}\right.$, $294 \mathrm{~K}): \delta 5.41(\mathrm{~s}, 2 \mathrm{H}, \mathrm{CH}), 2.04\left(\mathrm{~s}, 6 \mathrm{H}, \mathrm{CH}_{3}\right), 2.02\left(\mathrm{~s}, 6 \mathrm{H}, \mathrm{CH}_{3}\right)$. ${ }^{13} \mathrm{C} \mathrm{NMR}\left(\mathrm{CDCl}_{3}, 294 \mathrm{~K}\right): \delta 197.5(2 \mathrm{C}, \mathrm{CO}), 189.9$ (2C, CO), $189.0(2 \mathrm{C}, \mathrm{CO}), 100.6,(2 \mathrm{C}, \mathrm{CH}), 27.8\left(4 \mathrm{C}, \mathrm{CH}_{3}\right)$. Anal. Calcd for $\mathrm{C}_{12} \mathrm{H}_{14} \mathrm{O}_{6} \mathrm{Ru}: \mathrm{C}, 40.57 ; \mathrm{H}, 3.97$. Found: $\mathrm{C}, 40.19 ; \mathrm{H}, 4.22 \%$.

Synthesis of complex (4). A six-fold molar excess of (tfac)H $(1.71 \mathrm{~g})$ was added to $\mathrm{Ru}_{3}(\mathrm{CO})_{12}(0.8 \mathrm{~g})$ in $50 \mathrm{~mL}$ of hexane. The resulting mixture was heated to $170{ }^{\circ} \mathrm{C}$ for 24 hours, following which the volatiles were removed under vacuum. The yellow-orange solid product $(1.5 \mathrm{~g})$, which consists of three structural isomers, was obtained in $87 \%$ yield by reduced pressure distillation at $120{ }^{\circ} \mathrm{C}$ and at 500 mTorr using a Büchi GKR-51 distillation apparatus. Selected spectral data of 4: MS (EI, $\left.{ }^{102} \mathrm{Ru}\right): \mathrm{m} / z 464\left(\mathrm{M}^{+}\right)$. IR $\left(\mathrm{C}_{6} \mathrm{H}_{12}\right): v(\mathrm{CO}), 2073$ (s), 2011 (vs) $\mathrm{cm}^{-1}$.

A light yellow crystalline product, consisting of a single isomer (4a) with melting point $124-125^{\circ} \mathrm{C}$, was obtained by repeated recrystallization from methanol solution at room temperature.

Spectral data of (4a): MS (EI, $\left.{ }^{102} \mathrm{Ru}\right): \mathrm{m} / \mathrm{z} 464\left(\mathrm{M}^{+}\right)$. IR $\left(\mathrm{C}_{6} \mathrm{H}_{12}\right): v(\mathrm{CO}), 2073$ (s), 2011 (vs) $\mathrm{cm}^{-1} \cdot{ }^{1} \mathrm{H} \mathrm{NMR}\left(\mathrm{CDCl}_{3}\right.$ $294 \mathrm{~K}): \delta 5.85(\mathrm{~s}, 2 \mathrm{H}, \mathrm{CH}), 2.21\left(\mathrm{~s}, 6 \mathrm{H}, \mathrm{CH}_{3}\right) .{ }^{13} \mathrm{C} \mathrm{NMR}$ $\left(\mathrm{CDCl}_{3}, 298 \mathrm{~K}\right): \delta 198.4(2 \mathrm{C}, \mathrm{CO}), 195.2(2 \mathrm{C}, \mathrm{CO}), 169.0(\mathrm{q}$, $\left.2 \mathrm{C},{ }^{2} J_{\mathrm{CF}}=34 \mathrm{~Hz}\right), 118.0\left(\mathrm{q}, 2 \mathrm{C},{ }^{1} J_{\mathrm{CF}}=283 \mathrm{~Hz}\right), 95.8(2 \mathrm{C}$, $\mathrm{CH}), 28.9\left(2 \mathrm{C}, \mathrm{CH}_{3}\right) .{ }^{19} \mathrm{~F}\left(\mathrm{CDCl}_{3}, 298 \mathrm{~K}\right): \delta-74.44(\mathrm{~s}, 6 \mathrm{~F})$. Anal. Calcd for $\mathrm{C}_{12} \mathrm{H}_{8} \mathrm{~F}_{6} \mathrm{O}_{6} \mathrm{Ru}$ : C, 31.11; H, 1.74. Found: $\mathrm{C}$, $31.30 ; \mathrm{H}, 1.52 \%$.

A yellow-orange viscous liquid, which is composed of an inseparable mixture of the other isomers $(\mathbf{4 b})$ and $(\mathbf{4 c})$ and a very small amount of (4a), was obtained from reduced pressure distillation of the filtrate that was collected during recrystallization. Selected spectral data of a mixture of $(\mathbf{4 b})$ and $(\mathbf{4 c}):{ }^{1} \mathrm{H}$ NMR (4b, $\left.\mathrm{CDCl}_{3}, 294 \mathrm{~K}\right): \delta 5.90(\mathrm{~s}, 1 \mathrm{H}, \mathrm{CH}), 5.87(\mathrm{~s}, 1 \mathrm{H}, \mathrm{CH})$, $2.22\left(\mathrm{~s}, 3 \mathrm{H}, \mathrm{CH}_{3}\right), 2.21\left(\mathrm{~s}, 3 \mathrm{H}, \mathrm{CH}_{3}\right) .{ }^{19} \mathrm{~F}\left(\mathrm{CDCl}_{3}, 298 \mathrm{~K}\right): \delta$ $-73.75(\mathrm{~s}, 3 \mathrm{~F}),-74.57(\mathrm{~s}, 3 \mathrm{~F}) .{ }^{1} \mathrm{H}$ NMR $\left(4 \mathrm{c}, \mathrm{CDCl}_{3}, 294 \mathrm{~K}\right): \delta$ $5.88(\mathrm{~s}, 2 \mathrm{H}, \mathrm{CH}), 2.23\left(\mathrm{~s}, 6 \mathrm{H}, \mathrm{CH}_{3}\right) .{ }^{19} \mathrm{~F}\left(\mathrm{CDCl}_{3}, 298 \mathrm{~K}\right)$ : $\delta-73.70(\mathrm{~s}, 6 \mathrm{~F})$

\section{X-Ray crystallography}

Single crystal X-ray diffraction data were measured on a Nonius CAD4 diffractometer using $\lambda\left(\mathrm{Mo}-\mathrm{K}_{\alpha}\right)$ radiation $(\lambda=$ $0.71073 \AA$ ). Data collection was executed using the SMART program, while cell refinement and data reduction were carried out using the SAINT program. The structure was determined using the SHELXTL/PC program and refined using full-matrix least squares. All non-hydrogen atoms were refined anisotropically, whereas hydrogen atoms were placed at the calculated positions and included in the final stage of refinements with fixed parameters. Three fluorine atoms, $\mathrm{F}(4), \mathrm{F}(5)$ and $\mathrm{F}(6)$, of one of the $\mathrm{CF}_{3}$ groups were found to be disordered, and the occupancies $(50: 50 \%)$ were estimated according to the least 
squares refinement. Selected crystal data of (4a) are listed below:

$\mathrm{C}_{12} \mathrm{H}_{8} \mathrm{~F}_{6} \mathrm{O}_{6} \mathrm{Ru}, M=463.25$, triclinic, space group $P \overline{1}, a=$ 7.7805(8), $b=9.2982(2), c=12.251(2) \AA, \alpha=74.530(13), \beta=$ $83.433(13), \gamma=75.538(11)^{\circ}, V=826.0(2) \AA^{3}, Z=2$, $\rho_{\text {calcd }}=1.863 \mathrm{~g} \mathrm{~cm}^{-1}, F(000)=452$, crystal size $0.50 \times 0.50 \times$ $0.50 \mathrm{~mm}, \lambda\left(\mathrm{Mo}_{\alpha}\right)=0.7107 \AA, T=295 \mathrm{~K}, \mu=1.038 \mathrm{~mm}^{-1}$, 3797 reflections collected, 3797 unique $\left(R_{\text {int }}=0.0000\right)$, final $w R_{2}($ all data $)=0.0741 . R_{1}[I>2 \sigma(I)]=0.0267$.

CCDC reference number 201228. See http://www.rsc.org/ suppdata/jm/b3/b300517h/ for crystallographic data in CIF or other electronic format.

\section{CVD procedures}

The thermal CVD reactions were carried using a vertical coldwall reactor described elsewhere. ${ }^{13}$ For deposition of Ru metal, the sample reservoir was maintained at $28{ }^{\circ} \mathrm{C}$ and $50{ }^{\circ} \mathrm{C}$ for complex (1), and $80{ }^{\circ} \mathrm{C}$ for complex (2); while $\mathrm{RuO}_{2}$ thin films were deposited using pure $\mathrm{O}_{2}$ carrier gas. The flow rate of the carrier gas was adjusted to $10-20 \mathrm{sccm}$, the sample reservoir was loaded with $\sim 50 \mathrm{mg}$ of CVD source reagent, and the deposition time was set to a period of 20-40 min. Before each experiment, the $\mathrm{Si}$ wafers were rinsed with diluted aqueous solution of Buffered Oxide Etch 6:1 (J. T. Baker), followed by de-ionized water and acetone in sequence, and dried under nitrogen.

\section{Results and discussion}

\section{Synthesis and characterization of Ru complexes}

The ruthenium carbonyl complex $\mathrm{Ru}_{3}(\mathrm{CO})_{12}$ reacted with 6 eq. of the $\beta$-diketone ligands in pentane or hexane solution at 160 $170{ }^{\circ} \mathrm{C}$ to give the ruthenium complexes $\left[\mathrm{Ru}(\mathrm{CO})_{2}(\mathrm{hfac})_{2}\right](\mathbf{1})$, $\left[\mathrm{Ru}(\mathrm{CO})_{2}(\mathrm{tmhd})_{2}\right](\mathbf{2}),\left[\mathrm{Ru}(\mathrm{CO})_{2}(\mathrm{acac})_{2}\right](3)$ and $\left[\mathrm{Ru}(\mathrm{CO})_{2}(\mathrm{tfac})_{2}\right]$ (4) in good yields. The applied experimental procedures were essentially identical to that reported in the literature, except that a nonpolar and highly volatile hydrocarbon solvent was utilized to replace the polar THF solvent, the latter gave much lower yields due to apparent sample decomposition. ${ }^{14}$ The molecular structures and physical data of (1)-(4) are summarized in Scheme 1 and Table 1, respectively. The reaction stoichiometry giving the observed products can be understood according to the chemical equation listed below:

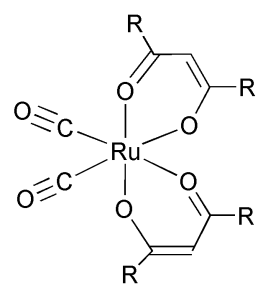

(1) $\mathrm{R}=\mathrm{CF}_{3}$

(2) $\mathrm{R}=\mathrm{t}-\mathrm{Bu}$

(3) $\mathrm{R}=\mathrm{Me}$

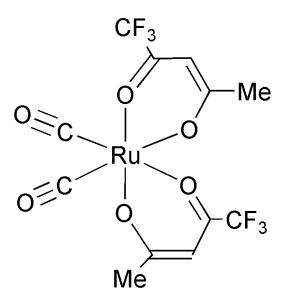

(4b)

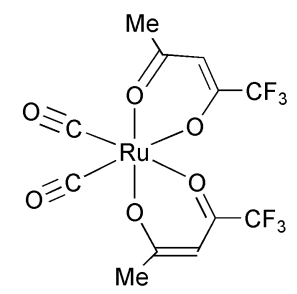

(4a)

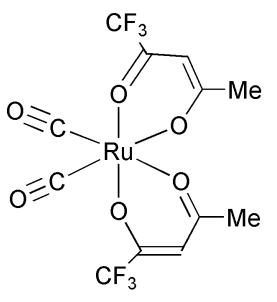

(4c)
Table 1 Physical properties of the dicarbonyl $\beta$-diketonato ruthenium complexes

\begin{tabular}{lccc}
\hline Formula and cmpd. no. & M.W. & M.P. $/{ }^{\circ} \mathrm{C}$ & $T_{1 / 2} /{ }^{\circ} \mathrm{C}^{a}$ \\
\hline$\left[\mathrm{Ru}(\mathrm{CO})_{2}(\mathrm{hfac})_{2}\right](\mathbf{1})$ & 571.19 & $64-66$ & 111 \\
{$\left[\mathrm{Ru}(\mathrm{CO})_{2}(\mathrm{tmhd})_{2}\right](\mathbf{2})$} & 523.62 & $70-72$ & 194 \\
{$\left[\mathrm{Ru}(\mathrm{CO})_{2}(\mathrm{acac})_{2}\right](\mathbf{3})$} & 355.31 & $115-117$ & 182 \\
{$\left[\mathrm{Ru}(\mathrm{CO})_{2}(\mathrm{tfac})_{2}\right](\mathbf{4})^{b}$} & 463.25 & $55-75$ & 140 \\
{$\left[\mathrm{Ru}(\mathrm{CO})_{2}(\mathrm{tfac})_{2}\right](\mathbf{4 a})$} & 463.25 & $132-133$ & 140
\end{tabular}

${ }^{a}$ The temperature at which 50 wt. $\%$ of the sample was lost during TGA analysis. ${ }^{b} \mathrm{~A}$ mixture of three structural isomers.

$$
\begin{aligned}
\mathrm{Ru}_{3}(\mathrm{CO})_{12}+6 & \text { (diketonate }) \mathrm{H} \rightarrow \\
& 3\left[\mathrm{Ru}(\mathrm{CO})_{2}(\text { diketonate })_{2}\right]+3 \mathrm{H}_{2}+6 \mathrm{CO}
\end{aligned}
$$

These ruthenium-containing metal complexes were purified by sublimation to remove trace amounts of black, non-volatile impurity, followed by recrystallization from a mixture of $\mathrm{CH}_{2} \mathrm{Cl}_{2}$ and methanol at room temperature. Their color varies from light orange, light yellow to yellow orange, respectively. The identification was achieved using FAB mass analysis, IR and NMR spectroscopy and elemental analysis. Of particular importance was the solution IR spectrum, for which two strong $v(C O)$ stretching absorptions in the range of 2092-1985 $\mathrm{cm}^{-1}$ were observed due to terminal CO ligands located in cispositions; ${ }^{15}$ the hfac complex (1) showed the highest stretching frequencies, i.e. at 2092 and $2036 \mathrm{~cm}^{-1}$. This observation is in good agreement with the electron withdrawing property of the hfac ligand, making it a poor $\sigma$-donor. The same electron withdrawing character then reduced the charge density on the $\mathrm{Ru}(\mathrm{II})$ metal center as well as the metal-to-ligand back $\pi$-bonding to the nearby carbonyl ligands. Moreover, the ${ }^{13} \mathrm{C}$ NMR chemical shifts of the terminal CO ligands follow a monotonous trend of $\delta 199.1$ (2) > 197.5 (3) $\gg 192.5$ (1); showing a systematic de-shielding effect imposed by the $\beta$-diketonate ligands.

Thermogravimetric analysis of (1) carried out at atmospheric pressure and with $\mathrm{N}_{2}$ as the carrier gas exhibited an onset of loss of weight at $60{ }^{\circ} \mathrm{C}$ due to the direct evaporation of the sample, affording a zero residual weight at $125^{\circ} \mathrm{C}$. On the other hand, the tert-butyl derivative $\left[\mathrm{Ru}(\mathrm{CO})_{2}(\mathrm{tmhd})_{2}\right](\mathbf{2})$, for which the tert-butyl groups are less effective in terms of reducing the intermolecular attraction, displayed a much higher onset temperature for sample evaporation at $130{ }^{\circ} \mathrm{C}$ and became completely vaporized upon raising the temperature to $215^{\circ} \mathrm{C}$. The repulsive interaction between the lone pairs of fluorine atoms and the low polarizability of the $\mathrm{C}-\mathrm{F}$ bonds are probably the two most important factors that contribute to the observed difference in volatility. ${ }^{16}$

In addition, the TG analysis of the parent acetylacetonate complex $\left[\mathrm{Ru}(\mathrm{CO})_{2}(\mathrm{acac})_{2}\right]$ (3) was recorded for comparison. Again, a single-stage loss of weight was observed, for which the starting temperature of sample evaporation was akin to that of (2), except that the vaporization proceeded slightly faster, giving a null residual weight at $\sim 200{ }^{\circ} \mathrm{C}$. The higher volatility of $(3)$ is apparently due to the smaller molecular weight, which would give weaker van der Waals attractive interactions between each of the individual molecules. However, the melting point of (2) is only $70-72{ }^{\circ} \mathrm{C}$, vs. the range of 115 $117{ }^{\circ} \mathrm{C}$ observed for (3); the former would be more suitable to use as a liquid precursor, ${ }^{17}$ which would show a more reproducible and steady rate of evaporation, by keeping the temperatures of the sample reservoir and transport lines slightly higher than its normal melting point.

For the reaction employing $\mathrm{Ru}_{3}(\mathrm{CO})_{12}$ and the asymmetric $\beta$-diketone ligand (tfac) $\mathrm{H}$, all three isomeric products $\left[\mathrm{Ru}(\mathrm{CO})_{2}(\mathrm{tfac})_{2}\right](4)$ were isolated by direct sublimation of the product mixture, showing a statistical, random distribution 


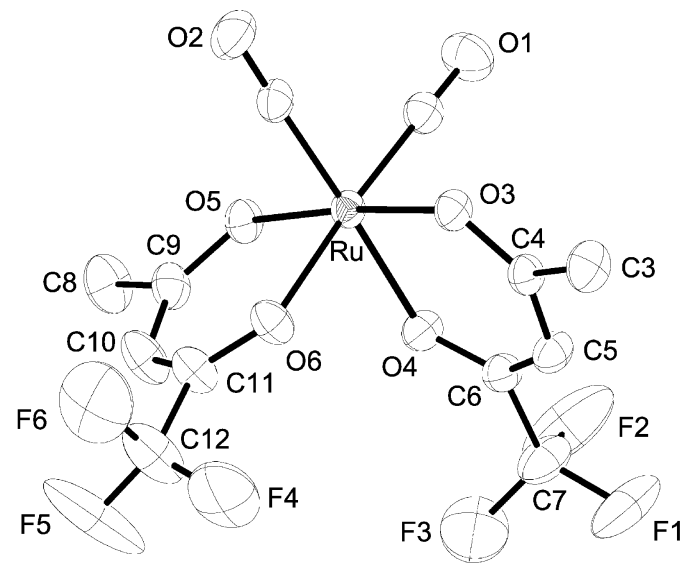

Fig. 1 Molecular structure of $\left[\mathrm{Ru}(\mathrm{CO})_{2}(\mathrm{tfac})_{2}\right]$ complex (4a). Selected bond lengths are given as follows: $\mathrm{Ru}-\mathrm{C}(1)=1.877(3), \mathrm{Ru}-\mathrm{C}(2)=$ $1.874(3), \mathrm{Ru}-\mathrm{O}(3)=2.052(2), \mathrm{Ru}-\mathrm{O}(4)=2.060(2), \mathrm{Ru}-\mathrm{O}(5)=$ $2.041(2)$ and $\mathrm{Ru}-\mathrm{O}(6)=2.061(2) \AA$.

of the alkyl groups of the coordinated $\beta$-diketonate ligands. This is evident by the observation of four equal intensity $\mathrm{CH}$ signals at $\delta 5.90(\mathbf{4 b}), 5.88(\mathbf{4 c}), 5.87(\mathbf{4 b})$ and $5.85(\mathbf{4 a})$ in the ${ }^{1} \mathrm{H}$ NMR spectrum of the directly sublimed sample, where the asymmetric isomer (4) (see Scheme 1) is expected to show two signals with equal intensity. Repeated recrystallization from saturated methanol solutions gave the isolation of a crystalline product (4a) with a melting point $\left(132-133^{\circ} \mathrm{C}\right)$ that was higher than that of the mixed products $\left(55-75^{\circ} \mathrm{C}\right)$. Single crystal $\mathrm{X}$-ray analysis was then carried out to determine its configuration. As indicated in Fig. 1, it shows the expected octahedral coordination arrangement with two cis-oriented $\mathrm{CO}$ ligands and a pair of chelating $\beta$-diketonate ligands, on which the $\mathrm{CF}_{3}$ substituents are located at the positions trans to the carbonyl ligands. Interestingly, a higher temperature, which is similar to that employed for the reactions of $\mathrm{Ru}_{3}(\mathrm{CO})_{12}$ and $\beta$-diketone ligands, is required for inducing isomerization between $\mathbf{4 a}, \mathbf{4 b}$ and $\mathbf{4 c}$. This observation is evidenced by the result that less than $5 \%$ and $53 \%$ of the other two isomers (4b) and (4c), respectively, were observed upon heating a hexane solution of (4a) at $170{ }^{\circ} \mathrm{C}$ in a stainless steel autoclave for $3 \mathrm{~h}$ and $12 \mathrm{~h}$.

\section{Deposition of Ru metal thin films}

Deposition of Ru metal thin film was conducted using a coldwall CVD reactor, with the substrates maintained at temperatures $300-450{ }^{\circ} \mathrm{C}$. For each CVD experiment, the source reagent $(\sim 50 \mathrm{mg})$ was vaporized at temperatures of $28-80{ }^{\circ} \mathrm{C}$ and under a pressure of 1-5 Torr, these parameters were finetuned according to the relative volatility of the source reagent employed. The carrier gas was either high purity $\mathrm{H}_{2}$ or a mixture of $2 \% \mathrm{O}_{2}$ in argon. At the end of each deposition experiment, a gradual decreasing of the system pressure was observed, showing the total consumption of the source reagents and requiring $\sim 40$ minutes. The combined CVD parameters are summarized in Table 2.

The first deposition experiment was carried out from source complex (1) and using the reductive carrier gas $\mathrm{H}_{2}$ at $350{ }^{\circ} \mathrm{C}$. The thin films showed a light gray and somewhat lustrous appearance. The resistivity was measured by the four-point probe method $(\rho=618 \mu \Omega \mathrm{cm})$, which deviates significantly from that of bulk Ru metal $\left(7.1 \mu \Omega \mathrm{cm}\right.$ at $\left.0{ }^{\circ} \mathrm{C}\right)$. We believe that this high resistivity is mainly caused by the excessive carbon present in the thin films (30 at.\% by XPS). Upon increasing the deposition temperature, the as-deposited thin films became much thicker, $3200 \AA$ at $400{ }^{\circ} \mathrm{C}$ and $4800 \AA$ at $450{ }^{\circ} \mathrm{C}$, respectively; obviously due to the more effective metal deposition. The color of the thin films changed from light gray to silvery white and the electrical resistivities dropped to values of 39-26 $\mu \Omega \mathrm{cm}$, giving an indication of the improved thin film purity. For comparison, similar $\mathrm{H}_{2}$ induced deposition of $\mathrm{Ru}$ metal was successfully achieved using several related carbonyl complexes $\mathrm{Ru}_{3}(\mathrm{CO})_{12},{ }^{7 b} \mathrm{Ru}(\mathrm{CO})_{4}(\mathrm{hfb})^{6}$ and $\left[\mathrm{Ru}(\mathrm{CO})_{3}\left(3,5-\left(\mathrm{CF}_{3}\right)_{2}-\mathrm{pz}\right)\right]_{2}, \mathrm{pz}=$ pyrazolate. ${ }^{18}$ In this case, the $\mathrm{H}_{2}$ carrier gas would prevent the inadvertent metal oxidation, which was reported for depositions using the alternative $\mathrm{O}_{2}$ carrier gas and gave rise to the formation of the $\mathrm{RuO}_{2}$ rutile phase, vide supra.

The scanning electron micrographs of these metal thin films are compiled in Fig. 2. A comparison of these pictures suggested an apparent distinction according to the applied deposition temperatures. At $350{ }^{\circ} \mathrm{C}$, the top surface appeared much smoother and the sizes of the microcrystalline grains were $\sim 50 \mathrm{~nm}$. Upon increasing the temperature to $400{ }^{\circ} \mathrm{C}$ and to $450{ }^{\circ} \mathrm{C}$, the crystalline grains on the substrate grew much larger and the surface morphology turned rougher. The XRD data (Fig. 3) were consistent with these observations: the thin film deposited at the lowest temperature of $350{ }^{\circ} \mathrm{C}$ was essentially featureless, showing one broad signal in the $2 \theta$ region between $42-45^{\circ}$. Upon increasing the temperature to $400{ }^{\circ} \mathrm{C}$, four diffraction signals due to the (100), (002), (101) and (102) planes of the hexagonal close packed (hcp) structure became visible. As their relative intensities were similar to those of the Ru bulk standard, it implied that the as-deposited thin film was composed of small crystallites with almost no orientation preferences. Finally, upon raising the temperature to $450{ }^{\circ} \mathrm{C}$, the XRD experiment showed a prominent increase of the (002) reflection at $2 \theta=42.2^{\circ}$ with respect to the other signals. This is attributed to the fact that the (001) planes have the shortest crystallographic inter-planar spacing within the hexagonal $\mathrm{Ru}$ lattice structure, and should be the most preferable growth direction under the condition of thermodynamic

Table 2 Experimental data of the CVD experiments

\begin{tabular}{|c|c|c|c|c|c|c|c|c|c|}
\hline Entry & Source & CGFR/sccm & $\begin{array}{l}T_{\mathrm{S}} / \\
{ }^{\circ} \mathrm{C}\end{array}$ & $\begin{array}{l}T_{\mathrm{D}} / \\
{ }^{\circ} \mathrm{C}\end{array}$ & $\begin{array}{l}P_{\mathrm{S}} / \\
\text { Torr }\end{array}$ & $\begin{array}{l}\text { Thickness/ } \\
\AA\end{array}$ & $\begin{array}{l}\text { D. Rate/ } \\
\AA \mathrm{min}^{-1}\end{array}$ & $\begin{array}{l}\text { Resistivity } \rho / \\
\mu \Omega \mathrm{cm}\end{array}$ & $\begin{array}{l}\text { Cont. } \\
\text { (at.\%) }\end{array}$ \\
\hline 1 & (1) & $\mathrm{H}_{2}(20)$ & 28 & 350 & 5 & 1600 & 23 & 618 & C: 30 \\
\hline 2 & (1) & $\mathrm{H}_{2}(20)$ & 28 & 400 & 5 & 3200 & 46 & 39 & O: 4 \\
\hline 3 & (1) & $\mathrm{H}_{2}(20)$ & 28 & 450 & 5 & 4800 & 69 & 26 & O: 4 \\
\hline 4 & (1) & $\mathrm{O}_{2}(2 \%) / \operatorname{Ar}(10)$ & 50 & 300 & 5 & 600 & 12 & 34 & C: $4 ;$ O: 8 \\
\hline 5 & (1) & $\mathrm{O}_{2}(2 \%) / \mathrm{Ar}(10)$ & 50 & 350 & 5 & 1450 & 28 & 15 & C: $2 ; \mathrm{O}: 3$ \\
\hline 6 & (1) & $\mathrm{O}_{2}(2 \%) / \operatorname{Ar}(10)$ & 50 & 400 & 5 & 5000 & 96 & 37 & C: $2 ; 0: 9$ \\
\hline 7 & (2) & $\mathrm{O}_{2}(2 \%) / \mathrm{Ar}(10)$ & 80 & 275 & 1 & 1400 & 31 & 206 & C: $22 ; \mathrm{O}: 3$ \\
\hline 8 & (2) & $\mathrm{O}_{2}(2 \%) / \operatorname{Ar}(10)$ & 80 & 325 & 1 & 1600 & 36 & 111 & C: 9; O: 1 \\
\hline 9 & (2) & $\mathrm{O}_{2}(2 \%) / \operatorname{Ar}(10)$ & 80 & 375 & 1 & 3000 & 67 & 24 & C: $2 ; \mathrm{O}: 6$ \\
\hline 10 & (1) & $\mathrm{O}_{2}(10)$ & 25 & 300 & 5 & 1600 & 80 & 218 & O: 52 \\
\hline 11 & (1) & $\mathrm{O}_{2}(10)$ & 25 & 350 & 5 & 4800 & 240 & 156 & O: 65 \\
\hline 12 & (1) & $\mathrm{O}_{2}(10)$ & 25 & 400 & 5 & 5400 & 270 & 170 & O: 65 \\
\hline
\end{tabular}

Abbreviations: CGFR: carrier gas flow rate, $T_{\mathrm{S}}$ : source temperature, $T_{\mathrm{D}}$ : deposition temperature, $P_{\mathrm{S}}$ : initial system pressure, D. Rate: deposition rate, and Cont.: content of non-metal elements determined by XPS. 

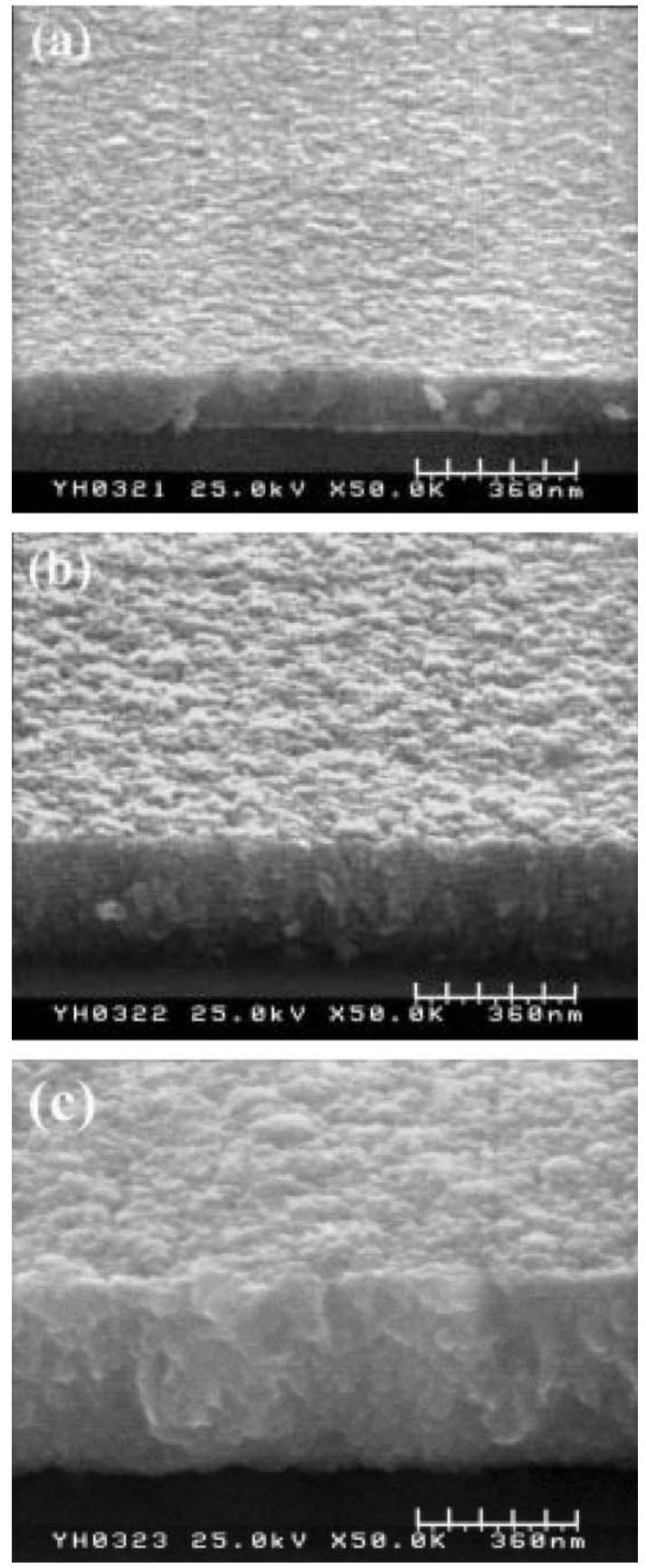

Fig. 2 SEM micrographs of the Ru films deposited from complex (1) under $\mathrm{H}_{2}$ atmosphere, deposition temperatures $T_{\mathrm{D}}$ being (a) $350^{\circ} \mathrm{C}$, (b) $400{ }^{\circ} \mathrm{C}$, and (c) $450{ }^{\circ} \mathrm{C}$.

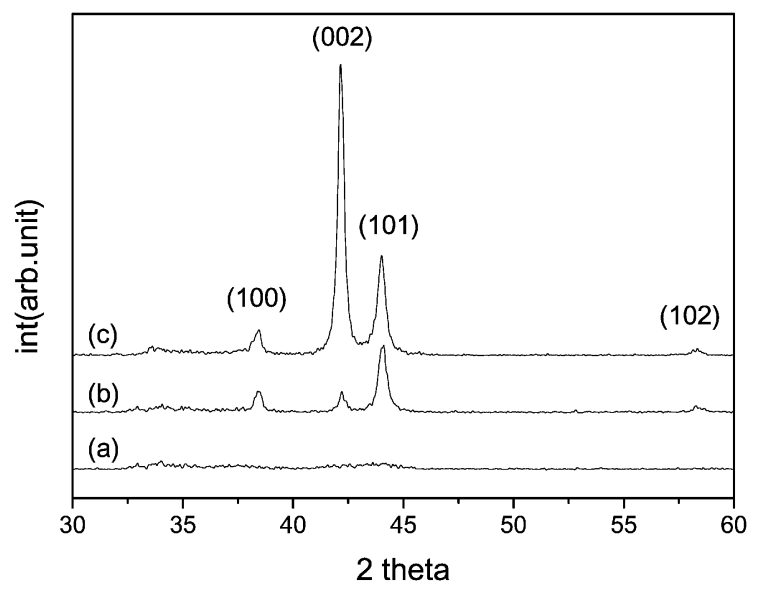

Fig. 3 X-Ray diffraction patterns for the Ru thin films deposited at temperatures $T_{\mathrm{D}}$ of (a) $350{ }^{\circ} \mathrm{C}$, (b) $400{ }^{\circ} \mathrm{C}$ and (c) $450{ }^{\circ} \mathrm{C}$.
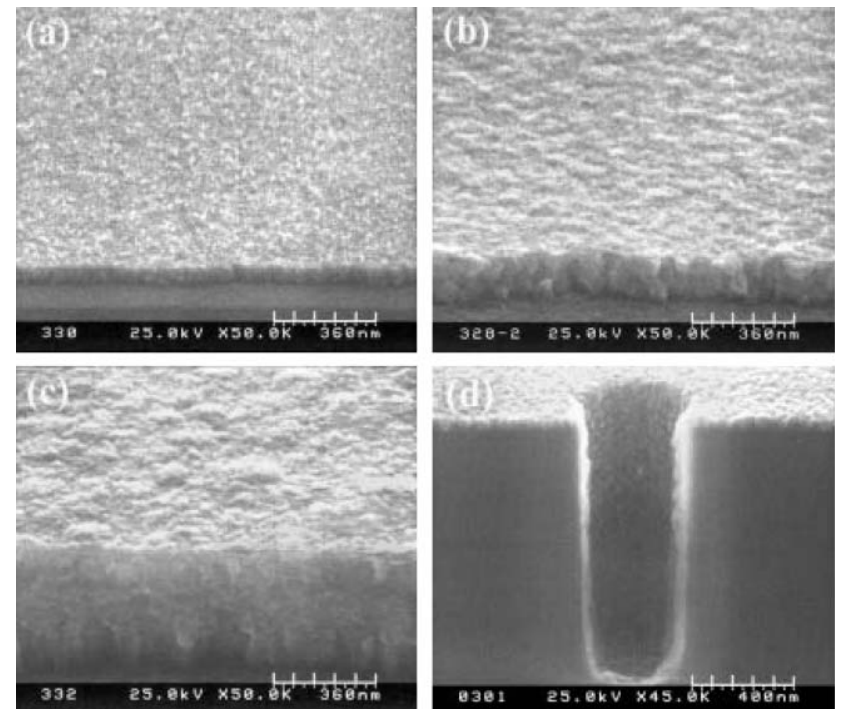

Fig. 4 SEM micrographs of the Ru films deposited from complex (1) under a mixture of Ar with $2 \%$ of $\mathrm{O}_{2}$, deposition temperatures $T_{\mathrm{D}}$ being (a) $300{ }^{\circ} \mathrm{C}$, (b) $350{ }^{\circ} \mathrm{C}$, (c) $400{ }^{\circ} \mathrm{C}$, and (d) $350{ }^{\circ} \mathrm{C}$ using a patterned thin film.

control. In accordance with this hypothesis, a high quality $c$-axis oriented $\mathrm{Ru}$ thin film was deposited on a glass substrate using dc magnetron sputtering. ${ }^{19}$

The deposition of $\mathrm{Ru}$ metal thin films was next conducted with complex (1) as the CVD precursor and a mixture of $2 \%$ oxygen in argon as the alternative carrier gas. The selection of this deposition parameter was encouraged by a recent report that the oxygen could enhance the oxidative ligand decomposition, resulting in metal deposition at lower temperatures, and then affecting the phase and other physical properties of the as-deposited thin film. ${ }^{20}$

For studying the deposition behavior under this new condition, the CVD runs were carried out at three temperatures: $300{ }^{\circ} \mathrm{C}, 350{ }^{\circ} \mathrm{C}$ and $400{ }^{\circ} \mathrm{C}$. The morphologies of the asdeposited thin films were investigated by scanning electron microscopy (Fig. 4). It can be seen that the thin film surfaces were smooth with neither pinholes nor cracks present between microcrystalline grains, particularly for the thin film grown at the limiting temperature of $300{ }^{\circ} \mathrm{C}$. Upon increasing the temperature to $350{ }^{\circ} \mathrm{C}$ and then to $400{ }^{\circ} \mathrm{C}$, the surface turned much rougher, along with an obvious increase of grain sizes and thickness. These observations are consistent with the general tend of the grain growth $v s$. applied deposition temperature. $^{21}$

X-Ray diffraction patterns of these thin films are compiled in Fig. 5. It is clear that the film deposited at $300{ }^{\circ} \mathrm{C}$ is amorphous

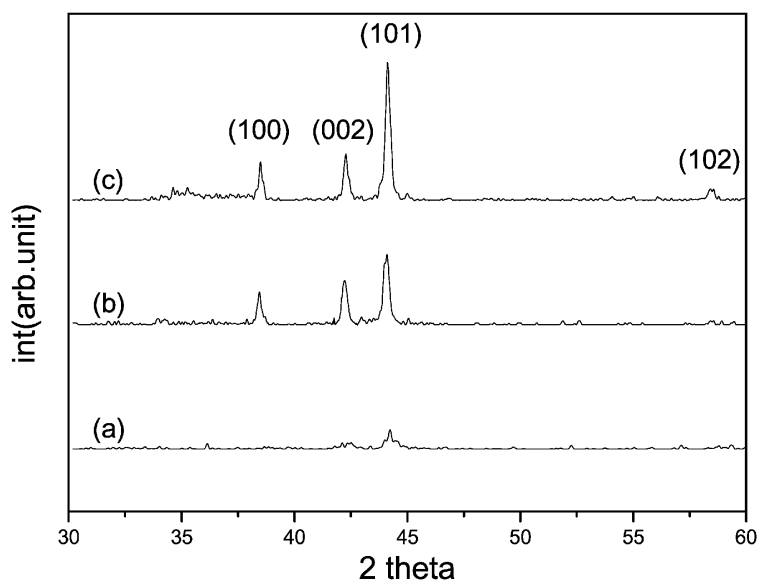

Fig. 5 X-Ray diffraction patterns for the Ru thin films deposited at temperatures $T_{\mathrm{D}}$ of (a) $300{ }^{\circ} \mathrm{C}$, (b) $350{ }^{\circ} \mathrm{C}$ and (c) $400{ }^{\circ} \mathrm{C}$. 
and shows a very broad signal in area expected for the hcp Ru metal. At $350{ }^{\circ} \mathrm{C}$, three signals due to the (100), (002) and (101) planes became visible, with intensities being very close to those of the powdery $\mathrm{Ru}$ standard. Upon further increasing the temperature to $400{ }^{\circ} \mathrm{C}$, the intensity pattern remained somewhat identical, except that the (101) diffraction signal grew slightly faster, showing the situation where there was no preferred orientation. This observation is in sharp contrast to the previous deposition experiment carried out under $\mathrm{H}_{2}$ carrier gas. In addition, the observed XRD patterns showed no other diffraction signal, in particular at the $2 \theta$ positions that could be assigned to the $\mathrm{RuO}_{2}$ rutile phase. This confirmed that the $2 \% \quad \mathrm{O}_{2}$ concentration would not promote the metal oxidation in giving the $\mathrm{RuO}_{2}$ oxide phase, but rather a ligand oxidation reaction. It then released the metallic $\mathrm{Ru}$ element and afforded the observed, high purity metal deposit on the substrates.

The resistivity of these thin film samples was then examined. As indicated in Table 2, they exhibited resistivity data in the range $37-15 \mu \Omega \mathrm{cm}$. The lowest resistivity was obtained with sample deposited at $350^{\circ} \mathrm{C}$, which was assigned as the optimal temperature for $\mathrm{Ru}$ metal deposition. In accordance with these results, X-ray photoelectron spectroscopy measurement (XPS) gives the carbon content at a level of 2-4 at.\%, while that of oxygen falls in a much larger range of 3-9 at.\%. Thus, the deviation from the ideal value of bulk Ru standard $(7.1 \mu \Omega \mathrm{cm})$ may be attributed to the incorporation of carbon and oxygen impurities as well as to the formation of many small crystallites in the as-deposited thin films.

For determination of the conformal deposition, we selected a patterned Si wafer containing through-holes with a diameter of $0.4 \mu \mathrm{m}$ and an aspect of $\sim 2$, and repeated the thin film depositions at the optimal temperature $350{ }^{\circ} \mathrm{C}$, using a mixture of Ar carrier gas with $2 \%$ oxygen and only one-third of the deposition time. The SEM picture of the as-deposited film is depicted in Fig. 4d. It is notable that through-holes have been evenly coated with a thin layer of ruthenium metal. The top surface of the resulting metal thin film appears smooth and featureless, and the thickness of the metal film within the holes is about the same as that deposited on the more exposed top surface, showing the good step coverage.

Moreover, the deposition of $\mathrm{Ru}$ metal was extended to experiments using the tmhd complex (2) and the carrier gas of $2 \%$ of oxygen in argon (Table 2 ). In order to balance the lower volatility of (2), increasing of the reservoir temperature to $80{ }^{\circ} \mathrm{C}$ and reduction of the system pressure to 1 Torr were employed to assist the vaporization and transport of the precursor. It was observed that the successful deposition of an $\mathrm{Ru}$ thin film was realized at all three temperature settings $\left(275,325\right.$ and $\left.375^{\circ} \mathrm{C}\right)$, which were slightly lower than those used for the hfac complex (1). Concurrently, the electrical resistivity of the thin films deposited at temperatures below $325{ }^{\circ} \mathrm{C}$ was found to be significantly greater than samples obtained at $375{ }^{\circ} \mathrm{C}$. In agreement with these resistivity data, XRD analysis showed that the thin films deposited at temperatures below $325^{\circ} \mathrm{C}$ were amorphous, and XPS fitting gave 9 at. $\%$ and 22 at. $\%$ of carbon content for the films deposited at $325{ }^{\circ} \mathrm{C}$ and $275{ }^{\circ} \mathrm{C}$, respectively. Based on these observations, we suggest that these as-deposited $\mathrm{Ru}$ thin films possess a strong tendency to incorporate high levels of carbon, making them less desirable for practical applications.

\section{Deposition of $\mathrm{RuO}_{2}$ thin films}

The $\mathrm{RuO}_{2}$ thin films were grown on Si substrates using (1) as the source reagent and using pure $\mathrm{O}_{2}$ as the carrier gas. As can be seen in Table 2, deposition occurred at temperatures as low as $300{ }^{\circ} \mathrm{C}$. The as-deposited thin films showed no cracks and adhered very well to the substrate surfaces, for which their SEM images are presented in Fig. 6. Columnar crystallite
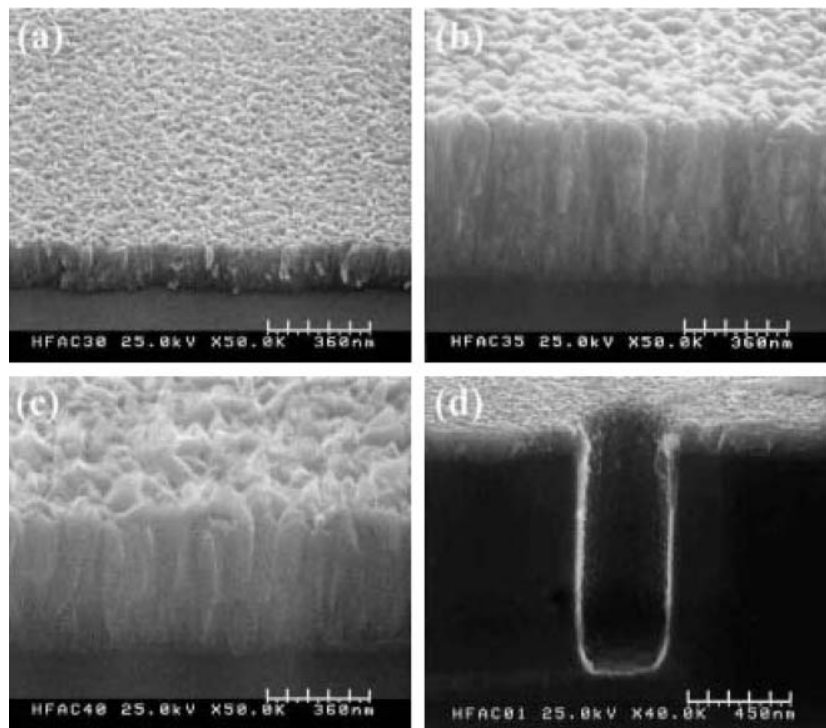

Fig. 6 SEM micrographs of the $\mathrm{RuO}_{2}$ films deposited from precursor (1), pure $\mathrm{O}_{2}$ as carrier gas, and with deposition temperatures $T_{\mathrm{D}}$ of (a) $300^{\circ} \mathrm{C}$, (b) $350{ }^{\circ} \mathrm{C}$, (c) $400{ }^{\circ} \mathrm{C}$, and (d) $350{ }^{\circ} \mathrm{C}$ using a patterned thin film.

grains and good coverage over the substrate surface were observed, which was attributed to the uninterrupted grain growth of the surface reaction controlled region. Moreover, the average grain size increases with increasing temperature, indicating that the grain growth is governed by the substrate temperature; i.e. the higher temperature provides greater kinetic energy to surpass the barrier for both crystal growth and boundary migration. Thus, the formation of larger crystallites on the substrate would occur through the reduction of the two-dimensional contact between the grains at higher temperature. For instance, the cross sectional view of the thin film deposited at $350{ }^{\circ} \mathrm{C}$ indicated the formation of a larger columnar structure perpendicular to the substrate and the top surface was made up of semi-ellipsoidal crystallites of similar sizes. At $400{ }^{\circ} \mathrm{C}$, the $\mathrm{RuO}_{2}$ film showed the columnar grains along with appreciable extrusions from its top surface, as compared with the morphologies observed at the lower temperatures. The resistivities of the films deposited at $300{ }^{\circ} \mathrm{C}$, $350{ }^{\circ} \mathrm{C}$ and $400{ }^{\circ} \mathrm{C}$ were $218 \mu \Omega \mathrm{cm}, 156 \mu \Omega \mathrm{cm}$ and $140 \mu \Omega \mathrm{cm}$, showing reduced resistivity with increasing deposition temperature. For comparison, epitaxial $\mathrm{RuO}_{2}$ films deposited on the (1102)-oriented $\mathrm{Al}_{2} \mathrm{O}_{3}$ single-crystal substrate surfaces exhibited a low electrical resistivity $\rho \sim 30 \mu \Omega \mathrm{cm}$ at room temperature. ${ }^{22}$

The X-ray diffraction patterns of the $\mathrm{RuO}_{2}$ films are depicted in Fig. 7. The formation of the tetragonal rutile $\mathrm{RuO}_{2}$ structure is confirmed using four main diffraction peaks including the

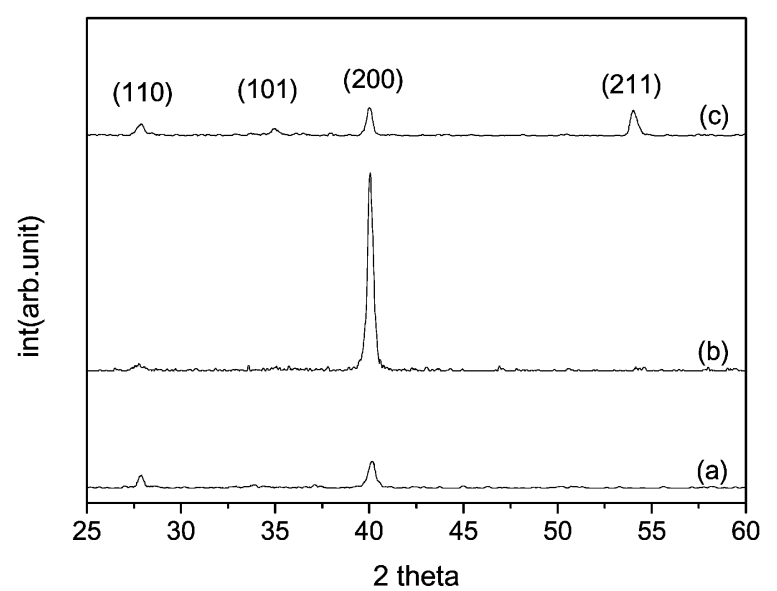

Fig. 7 X-Ray diffraction patterns for the $\mathrm{RuO}_{2}$ thin films deposited at temperatures $T_{\mathrm{D}}$ of (a) $300{ }^{\circ} \mathrm{C}$, (b) $350{ }^{\circ} \mathrm{C}$ and (c) $400{ }^{\circ} \mathrm{C}$. 

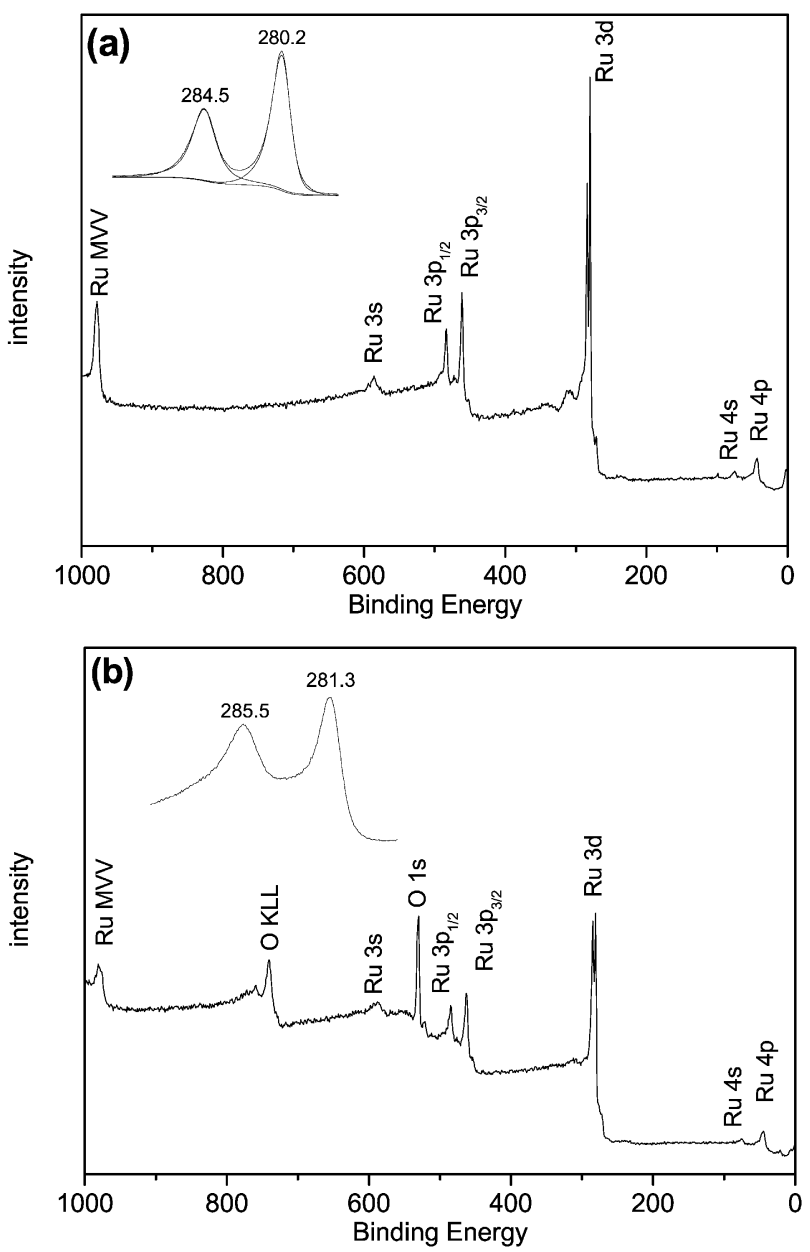

Fig. 8 XPS spectra of (a) ruthenium film deposited using $2 \%$ of $\mathrm{O}_{2}$ with $T_{\mathrm{D}}=400^{\circ} \mathrm{C}$, and (b) $\mathrm{RuO}_{2}$ film grown under $\mathrm{O}_{2}$ carrier gas and with $T_{\mathrm{D}}=350^{\circ} \mathrm{C}$. At the upper left corner of each spectrum, the dotted line shows the fitted $\mathrm{Ru} 3 \mathrm{~d}_{5 / 2}$ and $3 \mathrm{~d}_{3 / 2}$ doublet components of the thin film sample.

(110), (101), (200) and (211) planes of the $\mathrm{RuO}_{2}$ standard. It is noted that the film deposited at $300{ }^{\circ} \mathrm{C}$ exhibits two signals that were derived from the (110) and (200) planes with a 1:2 ratio. On the other hand, the film deposited at $350{ }^{\circ} \mathrm{C}$ shows notable (200) preference with respect to the other diffraction signals. In good agreement with our discovery, the formation of this (200) oriented, $\mathrm{RuO}_{2}$ thin film was obtained on the $\mathrm{LaAlO}_{3}(100)$ substrate with deposition temperatures greater than $500{ }^{\circ} \mathrm{C}$, while the latter has been attributed to the minimization of the lattice misfits present between the films and substrates. ${ }^{23}$ As the temperature was increased to $400{ }^{\circ} \mathrm{C}$, the thin film began to exhibit no specific preferred orientations, while the (211) signal gained its intensity and became equal to the (200) diffraction.

\section{XPS analysis}

Fig. 8a shows the XPS spectrum of the Ru thin film deposition from complex (1) at $T_{\mathrm{D}}=400{ }^{\circ} \mathrm{C}$ (thin film \#6). The fitting curves of the corresponding $\mathrm{Ru} 3 \mathrm{~d}_{5 / 2}$ and $3 \mathrm{~d}_{3 / 2}$ peaks at $\mathrm{BE}$ 280.2 and $284.5 \mathrm{eV}$ reveal the expected $3: 2$ ratio, ${ }^{24}$ while the very small deviation gives the relative content of carbon in the thin film sample $(\sim 2 \%)$. The XPS analyses of other $\mathrm{Ru}$ thin films were carried out accordingly and these analytical data are summarized in Table 2. Moreover, the presence of trace amounts of O-containing impurities and oxide phase $\mathrm{RuO}_{2}$ were evidenced by the detection of two relatively weak $\mathrm{O}(1 \mathrm{~s})$ XPS signals at $\mathrm{BE} \sim 530 \mathrm{eV}$.

For the $\mathrm{RuO}_{2}$ thin film deposited at $350{ }^{\circ} \mathrm{C}$ using pure $\mathrm{O}_{2}$ carrier gas (thin film \#11), the Ru (3d) XPS doublet was found at 281.3 and $285.5 \mathrm{eV}$ (Figure 8b), very close to the literature value of the $\mathrm{RuO}_{2} 3 \mathrm{~d}_{5 / 2}$ and $\mathrm{Ru} 3 \mathrm{~d}_{3 / 2}$ doublet peaks at $\mathrm{BE}$ 280.7-281.0 eV and BE 284.9-285.2 eV, respectively. ${ }^{25}$ The O(1s) XPS spectrum consists of an enhanced peak at $530.3 \mathrm{eV}$ and a shoulder at $532.3 \mathrm{eV}$. This XPS survey spectrum was qualitatively identical to that of the $\mathrm{RuO}_{2}$ thin film standard reported in the literature. ${ }^{26}$ Similar spectral patterns were observed for the two other samples; as a result, we proposed that the carbon impurity was below the detection limit.

\section{Summary}

The $\beta$-diketonate complexes $\left.\left[\mathrm{Ru}(\mathrm{CO})_{2} \text { (diketonate }\right)_{2}\right]$ were prepared and their basic properties fully characterized. For the methodology, although the need for a stainless autoclave is not attractive for routine laboratory use, its simplicity will make this method particularly suitable for the future industrial operations. Two of them, i.e. (1) and (2), may give properties superior to those of the most volatile carbonyl complexes, i.e. $\mathrm{Ru}(\mathrm{CO})_{5}{ }^{27}$ and $\mathrm{Ru}(\mathrm{CO})_{4}(\mathrm{hfb}),{ }^{6}$ and the commercially available liquid ruthenocene reagent $\mathrm{Ru}\left(\mathrm{C}_{5} \mathrm{H}_{4} \mathrm{Et}\right)_{2}{ }^{4}$

$\mathrm{Ru}$ metal thin films were fabricated from complex (1) and using $\mathrm{H}_{2}$ carrier gas. The depositions of $\mathrm{Ru}$ metal were next achieved from both (1) and (2), using the mixed carrier gas of $\mathrm{O}_{2}$ in argon. ${ }^{28}$ In this case, the precise control of oxygen partial pressure (i.e. $2 \%$ ) and accurate tuning of the deposition temperature are important; too high partial pressure of $\mathrm{O}_{2}$ as well as temperature would lead to the formation of a mixture of $\mathrm{Ru}$ and $\mathrm{RuO}_{2}$. In fact, such a mixed composition was obtained during our initial attempts in searching for the optimal $\mathrm{O}_{2} / \mathrm{Ar}$ ratio. Finally, depositions of conductive $\mathrm{RuO}_{2}$ were executed using (1) and pure $\mathrm{O}_{2}$ carrier gas, and well-defined $\mathrm{RuO}_{2}$ thin films with the preferred (200) orientation were obtained at $350{ }^{\circ} \mathrm{C}$, with the resistivity reduced to the lowest value of $156 \mu \Omega \mathrm{cm}$. Their physical properties were comparable to those of other $\mathrm{RuO}_{2}$ thin films obtained at higher temperatures. ${ }^{29}$

\section{Acknowledgements}

Y. C. thanks the National Science Council (NSC 91-2113-M007-006) as well as the Ministry of Economy (91-EC-17-A-08S1-0003) for financial support.

\section{References}

1 S. Yamamichi, P.-Y. Lesaicherre, H. Yamaguchi, K. Takemura, S. Sone, H. Yabuta, K. Sato, T. Tamura, K. Nakajima, S. Ohnishi, K. Tokashiki, Y. Hayashi, Y. Kato, Y. Miyasaka, M. Yoshida and H. Ono, IEEE Trans. Electron Devices, 1997, 44, 1076.

2 (a) E.-S. Choi, J.-B. Park and S.-G. Yoon, Chem. Vap. Deposit, 2001, 7, 260; (b) Y. Kim, S.-C. Ha, K.-C. Jeong, K. Hong, J.-S. Roh and H. K. Yoon, Integr. Ferroelectr., 2001, 36, 285; (c) M. Tarutani, M. Yamamuka, T. Takenaga, T. Kuroiwa and T. Horikawa, Thin Solid Films, 2002, 409, 8.

3 (a) D. E. Trent, B. Paris and H. H. Krause, Inorg. Chem., 1964, 3, 1057; (b) M. L. Green, M. E. Gross, L. E. Papa, K. J. Schnoes and D. Brasen, J. Electrochem. Soc., 1985, 132, 2677; (c) J. Si and S. B. Desu, J. Mater. Res., 1993, 8, 2644; (d) W.-C. Shin and S.-G. Yoon, J. Electrochem. Soc., 1997, 144, 1055.

4 (a) T. Aoyama and K. Eguchi, Jpn. J. Appl. Phys., 1999, 38, L1134; (b) Y. Matsui, M. Hiratani, T. Nabatame, Y. Shimamoto and S. Kimura, Electrochem. Solid-State Lett., 2002, 5, C18.

5 S. Uhlenbrock and B. A. Vaarstra, US Patent 1999, No. 5,962,716.

6 (a) Y. Senzaki, W. L. Gladfelter and F. B. McCormick, Chem. Mater., 1993, 5, 1715; (b) Y. Senzaki, D. Colombo, W. L. Gladfelter and F. B. McCormick, Proc. Electrochem. Soc., 1997, 97-25, 933.

7 (a) C. J. Smart, A. Gulhati and S. K. Reynolds, Mater. Res. Soc. Symp. Proc., 1995, 363, 207; (b) E. P. Boyd, D. R. Ketchum, H. Deng and S. G. Shore, Chem. Mater., 1997, 9, 1154.

8 (a) P. Hones, T. Gerfin and M. Graetzel, Appl. Phys. Lett., 1995, 67, 3078; (b) G.-R. Bai, A. Wang, C. M. Foster and J. Vetrone, Thin Solid Films, 1997, 310, 75; (c) J. M. Lee, J. C. Shin, C. S. Hwang, H. J. Kim and C.-G. Suk, J. Vac. Sci. Technol., 1998, 
16, 2768; (d) J.-H. Lee, J.-Y. Kim and S.-W. Rhee, Electrochem. Solid-State Lett., 1999, 2, 622; (e) D.-J. Lee, S.-W. Kang and S.-W. Rhee, Thin Solid Films, 2002, 413, 237; (f) K.-W. Kim, N.-S. Kim, Y.-S. Kim, I.-S. Choi, H.-J. Kim, J.-C. Park and S.-Y. Lee, Jpn. J. Appl. Phys., Part 1, 2002, 41, 820; (g) M. Kadoshima, T. Nabatame, M. Hiratani, Y. Nakamura, I. Asano and T. Suzuki, Jpn. J. Appl. Phys., Part 2, 2002, 41, L347.

9 L. Meda, R. C. Breitkopf, T. E. Haas and R. U. Kirss, Mater. Res. Soc. Symp. Proc., 1998, 495, 75.

10 (a) D. Barreca, A. Buchberger, S. Daolio, L. E. Depero, M. Fabrizio, F. Morandini, G. A. Rizzi, L. Sangaletti and E. Tondello, Langmuir, 1999, 15, 4537; (b) S. Barison, D. Barreca, S. Daolio, M. Fabrizio and E. Tondello, J. Mater. Chem., 2002, 12, 1511 .

11 (a) F.-J. Lee, Y. Chi, P.-F. Hsu, T.-Y. Chou, C.-S. Liu, S.-M. Peng and G.-H. Lee, Chem. Vap. Deposit., 2001, 7, 99; (b) Y. Chi, F.-J. Lee and C.-S. Liu, US Patent 2001, No. 6,303,809.

12 L. C. Feldman and J. W. Mayer, Fundamentals of Surface and Thin Film Analysis, North-Holland, New York, 1986, p. 354

13 (a) H.-L. Yu, Y. Chi, C.-S. Liu, S.-M. Peng and G.-H. Lee, Chem Vap. Deposit., 2001, 7, 245; (b) Y.-L. Chen, C.-S. Liu, Y. Chi, A. J. Carty, S.-M. Peng and G.-H. Lee, Chem. Vap. Deposit., 2002, $8,17$.

14 F. Calderazzo, C. Floriani, R. Henzi and F. L'Eplattenier, J. Chem. Soc. (A), 1969, 1378.

15 (a) I. R. Baird, S. J. Rettig, B. R. James and K. A. Skov, Can J. Chem., 1999, 77, 1821; (b) M. A. Bennett, G. Chung, D. C. R. Hockless, H. Neumann and A. C. Willis, J. Chem. Soc., Dalton Trans., 1999, 3451; (c) K.-B. Shiu, S.-J. Yu, Y. Wang and G.-H. Lee, J. Organomet. Chem., 2002, 650, 37.

16 (a) T. N. Martynova, L. D. Nikulina and V. A. Logvinenko, J. Thermal Anal., 1990, 36, 203; (b) I. K. Igumenov, V. R. Belosludov and P. A. Stabnikov, J. Phys. IV, 1999, 9, 15; (c) B. D. Fahlman and A. R. Barron, Adv. Mater. Opt. Electron., 2000, 10, 223; (d) Y. Chi, S. Ranjan, P.-W. Chung, C.-S. Liu, S.-M. Peng and G.-H. Lee, J. Chem. Soc., Dalton Trans., 2000, 343
17 (a) F. Maury, J. Phys. IV, 1995, C5, 449; (b) F. Maury, Chem. Vap. Deposit., 1996, 2, 113.

18 Y.-H. Song, Y.-L. Chen, Y. Chi, C.-S. Liu, W.-L. Ching, J. J. Kai, R.-S. Chen, Y.-S. Huang and A. J. Carty, Chem. Vap. Deposit., 2003, 9, in press.

19 Y. Abe, Y. Kaga, M. Kawamura and K. Sasaki, Jpn. J. Appl. Phys., 2001, 40, 6956.

20 (a) S.-E. Park, H.-M. Kim, K.-B. Kim and S.-H. Min, J. Electrochem. Soc., 2000, 147, 203; (b) Y.-H. Lai, T.-Y. Chou, Y.-H. Song, C.-S. Liu, Y. Chi, A. J. Carty, S.-M. Peng and G.-H. Lee, Chem. Mater., 2003, 15, in press.

21 J. J. Kim, D. H. Jung, M. S. Kim, S. H. Kim and D. Y. Yoon, Thin Solid Films, 2002, 409, 28.

22 K. Frohlich, D. Machajdik, V. Cambel, I. Kostic and S. Pignard, J. Cryst. Growth, 2002, 235, 377.

23 P. Lu, S. He, F. X. Li and Q. X. Ji, Thin Solid Films, 1999, 340, 140

24 (a) H. Kim, I. Rabelo de Moraes, G. Tremiliosi-Filho, R. Haasch and A. Wieckowski, Surf. Sci., 2001, 474, L203; (b) Y. Kaga, Y. Abe, H. Yanagisawa, M. Kawamura and K. Sasaki, Surf. Sci. Spectra, 1999, 6, 68.

25 H. Y. H. Chan, C. G. Takoudis and M. J. Weaver, J. Catal., 1997, 172, 336 .

26 J. Sankar, T. K. Sham and R. J. Puddephatt, J. Mater. Chem. 1999, 9, 2439.

27 A. D. Berry, D. J. Brown, R. Kaplan and E. J. Cukauskas, J. Vac. Sci. Technol. A, 1986, 4, 215.

28 (a) G. S. Sandhu, Thin Solid Films, 1998, 320, 1; (b) T. Aoyama, M. Kiyotoshi, S. Yamazaki and K. Eguchi, Jpn. J. Appl. Phys., 1999, 38, 2194; (c) E.-S. Choi, J.-C. Lee, J.-S. Hwang, J.-B. Park and S.-G. Yoon, J. Electrochem. Soc., 1999, 146, 4189; (d) Y. Matsui, M. Hiratani, T. Nabatame, Y. Shimamoto and S. Kimura, Electrochem. Solid-State Lett., 2001, 4, C9.

29 (a) P. Hones, F. Levy, T. Gerfin and M. Gratzel, Chem. Vap. Deposit., 2000, 6, 193; (b) R.-S. Chen, Y.-S. Huang, Y.-L. Chen and Y. Chi, Thin Solid Films, 2002, 413, 85 